Sains Malaysiana 50(2)(2021): 437-447

http://dx.doi.org/10.17576/jsm-2021-5002-15

\title{
Determinants of Pertussis among Young Children in Selangor, Malaysia
}

(Penentuan Pertusis dalam Kalangan Kanak-kanak di Selangor, Malaysia)

\author{
JULIANA MANSOR, HALIM ISMAIL* \& NORIAH ISMAIL
}

\begin{abstract}
The resurgence of pertussis infection worldwide, including Malaysia, is alarming. Young children have the highest reported pertussis incidence and death rates. However, little is known of the risk factors of pertussis in Malaysia. In this study, we aimed to determine the risk factors of pertussis infection among children. We conducted a case-control study involving 143 children aged $\leq 2$ years from Selangor, Malaysia. The children were identified from eNotifikasi, a webbased notification site, from 1 January to 31 December, 2018. Information on clinical presentation and risk factors were collected during investigation of the case by the district health office. Multivariate analysis showed that the odds for pertussis were higher among children aged $<3$ months (adjusted odds ratio (aOR) 5.54; 95\% confidence interval (CI); 1.835, 16.710) and among children who had not received their vaccination according to age (aOR 5.641; 95\% CI; $1.845,17.245)$. The mean duration of cough among the cases was 10.22 days (SD 8.964); that of the controls was 6.47 days (SD 7.098). Paroxysmal cough (93.6\%) was the predominant symptom among the cases. A total of $42.6 \%$ of cases were aged $<2$ months, whilst most of the controls were aged $>5$ months $(40.4 \%)$. Up to $42.6 \%$ of cases and $68.7 \%$ of controls were immunised according to their age. Therefore, it is important to ensure that children are vaccinated once they have attained the appropriate age.
\end{abstract}

Keywords: Children; DTaP; factors; immunization; pertussis

ABSTRAK

Kemunculan semula jangkitan pertusis atau batuk kokol di seluruh dunia, termasuk Malaysia, adalah membimbangkan. Kanak-kanak merupakan kumpulan dengan kadar insiden dan kematian tertinggi direkodkan. Walau bagaimanapun, maklumat risiko jangkitan tersebut amat sedikit di Malaysia. Oleh itu, kajian ini dijalankan bagi menentukan faktor risiko jangkitan pertusis dalam kalangan kanak-kanak. Kajian kes kawalan dijalankan melibatkan 143 kanak-kanak berusia $\leq 2$ tahun. Subjek dikenal pasti melalui sistem eNotifikasi dari 1 Januari sehingga 31 Disember, 2018. Maklumat berkaitan dengan tanda-tanda klinikal dan faktor risiko diperoleh semasa siasatan kes oleh pejabat kesihatan daerah. Analisis multivariat mendapati bahawa risiko penjangkitan pertusis adalah tinggi pada bayi berusia $<3$ bulan (aOR 5.54; 95\% CI; 1.835,16.710) dan kanak-kanak yang tidak menerima vaksinasi seperti dijadualkan (aOR 5.641; 95\% CI; 1.845,17.245). Purata jangka masa batuk dalam kalangan kes adalah 10.22 hari (SD 8.964); purata jangka masa batuk dalam kalangan kawalan adalah 6.47 hari (SD 7.098). Batuk paroksisma (93.6\%) merupakan gejala utama pada kes. Sejumlah $42.6 \%$ kes berusia $<2$ bulan, manakala majoriti kumpulan kawalan berusia $>5$ bulan (40.4\%). Sebanyak $42.6 \%$ kes dan $68.7 \%$ kawalan telah diberi vaksin mengikut jadual. Kesimpulannya, adalah penting bagi kanak-kanak diimunisasi mengikut jadual yang telah ditetapkan.

Kata kunci: DtaP; faktor; imunisasi; kanak-kanak; pertusis

\section{INTRODUCTION}

Children and young infants, especially those aged $\leq 2$ years, are vulnerable to infectious disease (Edwards 2014; Esposito \& Principi 2016). Many countries have introduced immunisation schedules for children as a preventive method against vaccine-preventable diseases (VPD) (WHO 2018a, 2015). Pertussis is a VPD and is an acute infection caused by the Gram-negative bacteria (WHO 2017a) Bordetella pertussis, which is transmitted person-to-person through direct contact with the airway 
secretions of an infected person or indirectly by touching a contaminated surface (WHO 2017a). To date, humans are the only known reservoir for B. pertussis (Tiwari 2005). However, a recent study in naive baboons noted that the species can be infected with $B$. pertussis (Warfel et al. 2016), and entirely airborne transmission of the bacteria can occur (Warfel et al. 2012). Pertussis tends to occur in younger infants and cause a severe life-threatening condition (Edwards 2014; Esposito \& Principi 2016).

In 2014, there were an estimated 24.1 million cases globally in children aged $<5$ years, including 5.1 million cases among infants (WHO 2018a; Yeung et al. 2017). The incidence rate of pertussis in Malaysia also shows an increasing trend, from $0.2 / 100,000$ population to $1.0 / 100,000$ population, over the past twenty years $(\mathrm{MOH}$ 2017). However, it is believed that the true incidence of pertussis is notably higher than the data captured by reporting and surveillance systems due to incorrect diagnosis, under-reporting and low consultation, especially among adolescents and adults with mild symptoms (Esposito \& Principi 2016). In Malaysia, pertussis is a mandatory notifiable disease and is monitored under a surveillance system (WHO 2018b). Besides, the increasing prevalence of pertussis infection increases the healthcare burden (Koh et al. 2016; Van Hoek et al. 2014). For pertussis cases, the estimated overall loss of quality of life is 0.097 quality-adjusted life years (QALYs) (Van Hoek et al. 2014). In 2012, the medical-related cost in Malaysia was around 2\% of the average monthly wage (Koh et al. 2016).

Multiple international studies have shown a number of risk factors linked to pertussis infection, such as waning immunity against pertussis in the community (Cherry 2012), infection transmission from asymptomatic individuals (Althouse \& Scarpino 2015) and vaccine refusal or delay (Glanz et al. 2013). However, research on this issue in Malaysia is very scarce. Furthermore, the increasing trend of the anti-vaccine movement adds to the underlying problem of vaccine defaulters, thus contributing to the resurgence of pertussis. Unpublished data by the Ministry of Health Malaysia ( $\mathrm{MOH})$ shows that the number of vaccine refusal cases increased from 600 in 2013 to 1600 in 2016 (Faridah 2017). Although the vaccination rate in Malaysia has always been high (WHO 2018a; 2018b), there remain pockets of vaccine refusal in many communities. This poses a threat to the local population, as the risk for VPD outbreak, including pertussis is high (Phadke et al. 2016; Smith 2017). Thus, the main aim of the present study was to determine the risk factors associated with pertussis infection among children in Selangor and to describe the clinical presentation of the cases.

\section{MATERIALS AND METHODS}

\section{STUDY SETTING}

According to Malaysia' Act 342 (LOM 2006), all suspected pertussis cases must be notified to the nearest district health office. All notified cases are captured in the real-time, web-based notification system, eNotifikasi. Any suspected case with suggestive clinical features of pertussis infection diagnosed by health facilities must be notified to the nearest district health office (DHO). A confirmatory laboratory test, either by PCR or culture, must proceed together with the notification. A positive test is classified as a confirmed case. In Malaysia, PCR is mainly used for laboratory confirmation of pertussis, as it yields results quickly (DCD 2010). Subsequently, the DHO investigates each notified case using a Pertussis Investigation Form. Here, we conducted a case-control study using the data captured in the form in Selangor, Malaysia from 1 January, 2018 to 31 December, 2018.

\section{SAMPLE SIZE}

The minimum sample size calculated using PS: Power and Sample Size Calculation (Dupont \& Plummer 2009) based on multiple risk factors (Curtis et al. 2017; Deeks et al. 1999; Glanz et al. 2013), with a confidence interval (CI) of $95 \%$ and power of $80 \%$, was 150 (50 cases and 100 controls), allowing for a $20 \%$ missing data rate.

\section{SAMPLE SELECTION}

Stratified random sampling was performed (Figure 1). Initially, a list of positive and negative cases was obtained from the eNotifikasi system. Both lists were stratified into all nine districts in Selangor based on the addresses. Then, a proportion of positive cases was selected from each district based on the total number of cases required using the simple random technique by SPSS software (IBM 2013). Cases were defined as children aged $\leq 2$ years with laboratory-confirmed pertussis. For every case, we included two controls from the same district. Controls were captured from the list of discarded (negative) cases using the simple random technique. Children were excluded if the DHO had been unable to investigate them and if the child had died during the investigation. The same applied to the control, with the additional exclusion criterion of no sample obtained. 


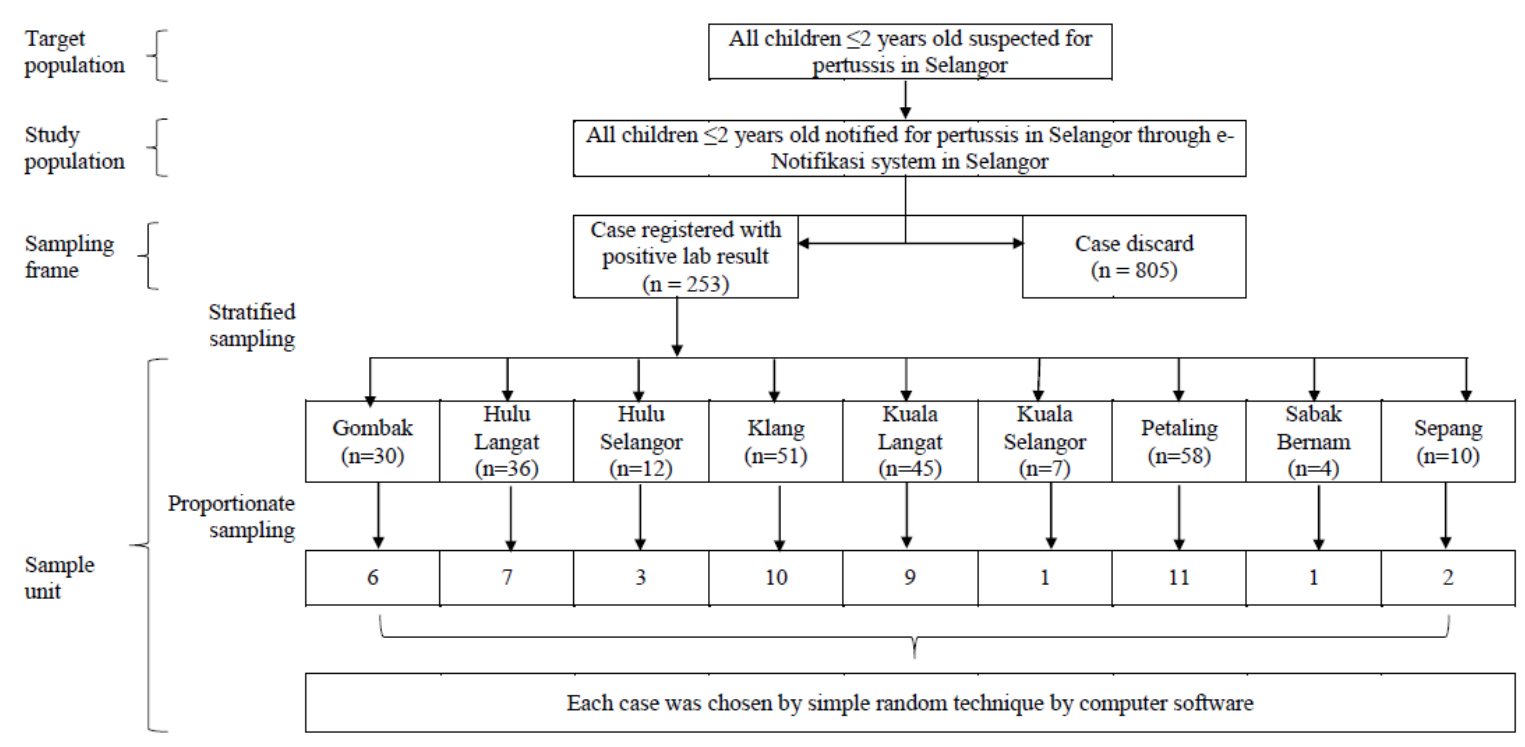

FIGURE 1. The sampling protocol for the study

\section{INSTRUMENTS}

The form includes demographic data, signs and symptoms, complications, immunisation status, breastfeeding status, suspected sources of infection, and laboratory results. Information on clinical signs and symptoms and complications related to pertussis was obtained for both groups. The risk covariates were divided into two groups: The individual's covariates: age (0-1 months, 2 months, 3-4 months, $\geq 5$ months), sex (male/female), race (Malay/Chinese/Indian/Other), immunisation status (ageappropriate immunisation: dose 1 at 2 months, dose 2 at 3 months, dose 3 at 5 months, booster dose at 18 months; those with age-appropriate immunisation were classified as yes; those aged $<2$ months were classified as unqualified for immunisation) and number of doses $(0 / 1 / 2 / 3 / 4)$, breastfeeding status (breastfeeding/mixed feeding/ formula milk feeding); Their contacts' covariates: Source of infection (household/other/unknown) and symptom status (symptomatic/asymptomatic). In Malaysia, pertussis immunisation is administered through the DiphtheriaTetanus-acellular Pertussis (DTaP) vaccine, with primary doses given at 2, 3 and 5 months, and a booster dose at 18 months. The presence of any type of complication was classified as yes.

\section{STATISTICAL ANALYSIS}

All data collected and extracted were analysed using the software Statistical Package for the Social Sciences version 22 (SPSS 22) (IBM 2013). Categorical data are expressed as frequencies (n) and percentage (\%); continuous data are expressed as the mean and standard deviation (SD). Bivariable comparison of risk factors between the cases and controls was calculated using simple logistic regression; the multivariable test using stepwise logistic regression was performed to assess the impact of several factors on the likelihood of pertussis infection and for obtaining important risk factors of pertussis infection. The odds ratio (OR) for each independent variable in the model was estimated using a logistic regression coefficient. A $p$-value $<0.05$ was used as the level of significance. Interaction and multicollinearity were checked.

\section{ETHICAL APPROVAL}

This research was approved by the National Medical Research Registry of Malaysia (NMRR ID: NMRR-19534-46053) and the Research Ethics Committee (REC) of Universiti Kebangsaan Malaysia (Ref no.: UKM PPI.8001/1/5/JEP-2019-405).

\section{RESULTS}

Out of 1085 notifications, a total of 256 laboratoryconfirmed cases were recorded in Selangor from 1 January, 2018, until 31 December, 2018, of which 253 cases $(98.8 \%)$ were children. Of these, $241(95 \%)$ were $\leq 2$ years old. A final 146 children were enrolled in the study: 
47 pertussis cases and 97 negative controls. The mean age of the cases was 3.9 months (SD 4.4) months; $51.1 \%$ were female (Table 1). The majority of cases were Malaysian citizens $(97.9 \%)$ and were Malay (91.5\%). Only $42.6 \%$ of cases had received immunisation according to age; $68.7 \%$ of the control group had been immunised up-toage. Around $55.3 \%$ of the cases had never have received any DTaP vaccine previously; in contrast, the control group had a lower portion of unimmunised children, i.e. $29.3 \%$. Regarding the source of infection, $51.1 \%$ of the cases and $53.5 \%$ of the controls were unsure of the suspected source, with no or unknown contact with an ill person. Most of the children were born at term and were breastfed solely or were on mixed feeding. Regarding clinical presentation, the mean days of cough before cases received treatment was 10.2 days; only $30 \%$ of cases had a history of prolonged cough for $>14$ days. The top three common symptoms the cases experienced were paroxysmal cough (93.6\%), fever (57.4\%) and post-tussive vomiting $(51.1 \%)$; the most common complication was pneumonia (21.3\%) (Figures $2 \& 3$ ).

TABLE 1. Descriptive analysis showing the characteristics of the children

\begin{tabular}{|c|c|c|c|c|}
\hline \multirow{2}{*}{\multicolumn{2}{|c|}{ Case }} & \multicolumn{2}{|c|}{$\mathrm{n}(\%)$} & \multirow[t]{2}{*}{ Total } \\
\hline & & \multicolumn{2}{|l|}{ Control } & \\
\hline \multicolumn{5}{|c|}{ Socio-demographics } \\
\hline \multirow[t]{2}{*}{ Citizenship } & Malaysian & $46(97.9)$ & $97(98.0)$ & $143(97.9)$ \\
\hline & Non-Malaysian & $1(2.1)$ & $2(2.0)$ & $3(2.1)$ \\
\hline \multirow[t]{6}{*}{ Age (months) } & Mean (SD) & $3.94(4.37)$ & $4.93(4.01)$ & \\
\hline & & $9(((4.3706)$ & $((4.0090)$ & \\
\hline & $0-1$ & $9(19.1)$ & $15(15.2)$ & $24(16.4)$ \\
\hline & 2 & $20(42.6)$ & $18(18.2)$ & $38(26.0)$ \\
\hline & $3-4$ & $7(14.9)$ & $26(26.3)$ & $33(22.6)$ \\
\hline & $\geq 5$ & $11(23.4)$ & $40(40.4)$ & $51(34.9)$ \\
\hline \multirow[t]{4}{*}{ Race } & Malay & $43(91.5)$ & $93(93.9)$ & $136(93.2)$ \\
\hline & Chinese & $1(2.1)$ & $0(0)$ & $1(0.7)$ \\
\hline & Indian & $2(4.3)$ & $2(2)$ & $4(2.7)$ \\
\hline & Other & $1(2.1)$ & $4(4)$ & $5(3.4)$ \\
\hline \multirow[t]{2}{*}{ Sex } & Male & $23(48.9)$ & $56(56.6)$ & $79(54.1)$ \\
\hline & Female & $24(51.1)$ & $43(43.4)$ & $67(45.9)$ \\
\hline \multicolumn{2}{|c|}{ Clinical presentation: Days of cough before seeking } & $10.22(8.96)$ & $6.97(7.10)$ & \\
\hline \multicolumn{5}{|c|}{ treatment, mean (SD) } \\
\hline \multicolumn{2}{|c|}{ Presence of complications: Yes } & $11(23.4)$ & $37(37.4)$ & $48(32.9)$ \\
\hline \multicolumn{5}{|l|}{ Immunisation } \\
\hline Age-appropriate & Yes & $20(42.6)$ & $68(68.7)$ & $88(60.3)$ \\
\hline \multirow[t]{2}{*}{ immunisation } & Unqualified & $15(31.9)$ & $23(23.2)$ & $38(26.0)$ \\
\hline & No & $12(25.5)$ & $8(8.1)$ & $20(13.7)$ \\
\hline \multirow[t]{5}{*}{ DTaP dose } & 1 & $12(25.5)$ & $16(16.2)$ & $28(19.2)$ \\
\hline & 2 & $3(6.4)$ & $22(22.2)$ & $25(17.1)$ \\
\hline & 3 & $6(12.8)$ & $31(31.3)$ & $37(25.3)$ \\
\hline & 4 & 0 & $1(1)$ & $1(0.7)$ \\
\hline & 0 & $26(55.3)$ & $29(29.3)$ & $55(37.7)$ \\
\hline
\end{tabular}




\begin{tabular}{|c|c|c|c|c|}
\hline \multicolumn{5}{|l|}{ Source and contact } \\
\hline Suspected source of & Household & $20(42.6)$ & $29(29.3)$ & 49 (33.6) \\
\hline \multirow{2}{*}{ infection } & Unknown & $24(51.1)$ & $53(53.5)$ & $77(52.7)$ \\
\hline & Other & $3(6.4)$ & $17(17.2)$ & $20(13.7)$ \\
\hline \multirow[t]{2}{*}{ Contact health status } & Symptomatic (Yes) & $19(40.4)$ & $36(36.4)$ & $55(37.7)$ \\
\hline & Asymptomatic (No/unknown) & $28(59.6)$ & $63(63.6)$ & $91(62.3)$ \\
\hline \multirow{3}{*}{$\begin{array}{l}\text { Relationship of } \\
\text { symptomatic contact }\end{array}$} & Household & $16(34)$ & $25(25.3)$ & $41(28.1)$ \\
\hline & Other & $5(10.6)$ & $14(14.1)$ & $19(13.0)$ \\
\hline & Not relevant & $26(55.3)$ & $60(60.6)$ & $86(58.9)$ \\
\hline \multicolumn{5}{|l|}{ Birth and feeding } \\
\hline \multirow[t]{2}{*}{ Gestation } & Term & $40(85.1)$ & $84(84.8)$ & $124(84.9)$ \\
\hline & Preterm & $7(14.9)$ & $15(15.2)$ & $22(15.1)$ \\
\hline \multirow[t]{3}{*}{ Feeding status } & Breastfeeding only & $24(51.1)$ & $38(38.4)$ & $62(42.5)$ \\
\hline & Formula milk & $3(6.4)$ & $19(19.2)$ & $22(15.1)$ \\
\hline & Mixed feeding & $20(42.6)$ & $42(42.4)$ & $62(15.1)$ \\
\hline
\end{tabular}

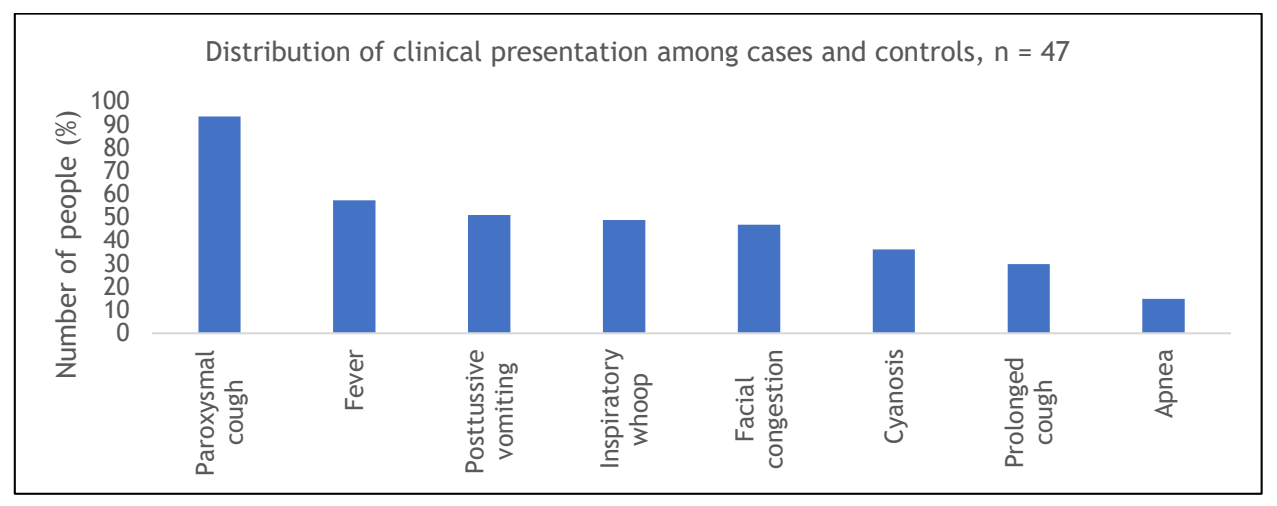

FIGURE 2. The distribution of clinical presentation among the cases and controls

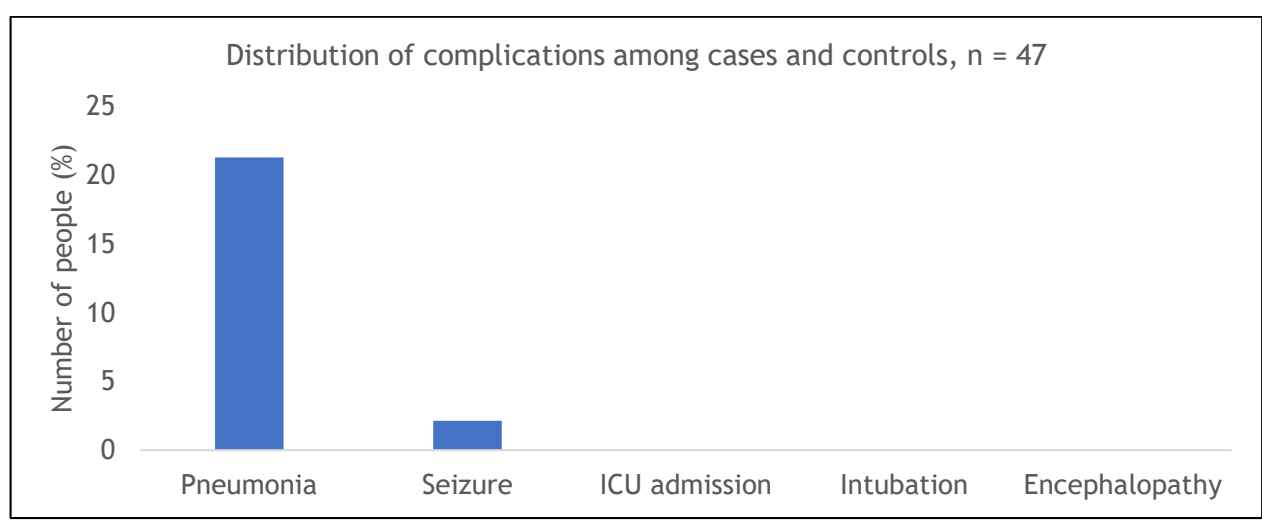

FIGURE 3. The distribution of complications among the cases and controls 
In the bivariable analysis, only the risk factors were analysed. We did not analyse the clinical presentation and complications further. The analysis showed three significant factors: Age group, immunisation status and DTaP vaccine dosage received (Table 2). Infants aged 2 months had 4.04 greater odds of being infected compared to those aged $\geq 3$ months $(p=0.003)$. Children who had not been immunised according to their age were
5.1 more likely to develop pertussis than those who had been immunised accordingly $(p=0.002)$. Children who had received two $(p=0.019)$ and three doses $(p=0.021)$ were 1.5-2 times less likely to be infected compared to those who did not receive any vaccination. The more DTaP dosages received, the less likely the child would be infected.

TABLE 2. Association of risk factors with pertussis infection

\begin{tabular}{|c|c|c|c|c|c|}
\hline \multicolumn{2}{|c|}{ Variables } & \multirow{2}{*}{$\begin{array}{c}\text { Crude OR } \\
0.95\end{array}$} & \multirow{2}{*}{$\begin{array}{c}95 \% \mathrm{CI} \\
0.08,10.73\end{array}$} & \multirow{2}{*}{$\frac{\chi^{2}(\mathrm{df})^{\mathrm{a}}}{0.01(1)}$} & \multirow{2}{*}{$\frac{p \text {-value }}{0.966}$} \\
\hline Citizenship & Malaysian & & & & \\
\hline & Non-Malaysian & 1.00 & & & \\
\hline \multirow[t]{2}{*}{ Race } & Malay & 0.69 & $0.19,2.59$ & $0.29(1)$ & 0.590 \\
\hline & Non-Malay & 1.00 & & & \\
\hline \multirow[t]{2}{*}{ Sex } & Male & 0.74 & $0.37,1.48$ & $0.75(1)$ & 0.388 \\
\hline & Female & 1.00 & & & \\
\hline \multirow[t]{5}{*}{ Age, months } & & & & $11.85(3)$ & 0.008 \\
\hline & $0-1$ & 2.18 & $0.75,6.31$ & $2.07(1)^{\mathrm{b}}$ & $0.150^{\mathrm{b}}$ \\
\hline & 2 & 4.04 & $1.61,10.16$ & $8.80(1)^{\mathrm{b}}$ & $0.003^{\mathrm{b}}$ \\
\hline & $3-4$ & 0.98 & $0.34,2.85$ & $0.002(1)^{b}$ & $0.969^{\mathrm{b}}$ \\
\hline & $\geq 5$ & 1.00 & & & \\
\hline \multirow[t]{2}{*}{ Complications } & Yes & 0.51 & $0.23,1.13$ & $2.92(1)$ & 0.088 \\
\hline & No & 1.00 & & & \\
\hline Age-appropriate & & & & $11.23(2)$ & 0.004 \\
\hline \multirow[t]{3}{*}{ immunisation } & Yes & 1.00 & & & \\
\hline & Unqualified & 2.22 & $0.98,5.03$ & $3.63(1)^{\mathrm{b}}$ & $0.057^{\mathrm{b}}$ \\
\hline & No & 5.10 & $1.83,14.20$ & $9.72(1)^{\mathrm{b}}$ & $0.002^{\mathrm{b}}$ \\
\hline \multirow[t]{6}{*}{ DTaP dose } & & & & $17.99(4)$ & 0.001 \\
\hline & 1 & 0.84 & $0.33,2.09$ & $0.15(1)^{\mathrm{b}}$ & $0.70^{\mathrm{b}}$ \\
\hline & 2 & 0.15 & $0.04,0.57$ & $7.85(1)^{\mathrm{b}}$ & $0.019^{\mathrm{b}}$ \\
\hline & 3 & 0.22 & $0.08,0.60$ & $8.65(1)^{b}$ & $0.021^{\mathrm{b}}$ \\
\hline & 4 & $<0.01$ & $<0.01$ & $<0.01(1)^{\mathrm{b}}$ & $1.000^{\mathrm{b}}$ \\
\hline & 0 & 1.00 & & & \\
\hline \multicolumn{2}{|l|}{ Suspected source of } & & & $4.74(2)$ & 0.093 \\
\hline \multirow[t]{3}{*}{ infection } & Household & 3.91 & $1.01,15.12$ & $3.90(1)^{\mathrm{b}}$ & $0.048^{\mathrm{b}}$ \\
\hline & Unknown & 2.57 & $0.69,9.59$ & $1.96(1)^{\mathrm{b}}$ & $0.161^{\mathrm{b}}$ \\
\hline & Other & 1.00 & & & \\
\hline
\end{tabular}




\begin{tabular}{|c|c|c|c|c|c|}
\hline Contacts' health status & Yes & 1.19 & $0.58,2.42$ & $0.22(1)$ & 0.637 \\
\hline (Symptomatic) & No/unknown & 1.00 & & & \\
\hline Relationship of & & & & $1.31(2)$ & 0.519 \\
\hline symptomatic contact & Household & 1.48 & $0.68,3.22$ & $0.97(1)^{\mathrm{b}}$ & $0.33^{\mathrm{b}}$ \\
\hline \multirow[t]{2}{*}{ to case } & Other & 0.82 & $0.27,2.53$ & $0.12(1)^{\mathrm{b}}$ & $0.735^{\mathrm{b}}$ \\
\hline & Not relevant & 1.00 & & & \\
\hline \multirow[t]{2}{*}{ Gestation } & Term & 1.00 & & & \\
\hline & Preterm & 1.02 & $0.39,2.70$ & $0.01(1)$ & 0.968 \\
\hline \multirow[t]{4}{*}{ Feeding status } & & & & $5.21(2)$ & 0.074 \\
\hline & Breastfeeding & 1.00 & & & \\
\hline & Formula milk & 0.25 & $0.07,0.94$ & $4.23(1)^{\mathrm{b}}$ & $0.040^{\mathrm{b}}$ \\
\hline & Mixed feeding & 0.75 & $0.36,1.58$ & $0.56(1)^{\mathrm{b}}$ & $0.453^{\mathrm{b}}$ \\
\hline
\end{tabular}

a Likelihood ratio test, ${ }^{\mathrm{b}}$ Wald test, df, Degree of freedom

Multivariable analysis was performed using all variables that were significant in the bivariable analysis. The final backward stepwise model containing both predictors was statistically significant $\left(\chi^{2}(6, \mathrm{n}=146)\right.$ $=22.013, p=0.001)$. The model correctly classified $71.2 \%$ of cases. Neither interaction nor collinearity was present. Infants aged $<3$ months had 5.5 times greater odds of being infected compared to those aged $\geq 5$ months. Meanwhile, children who had never received any vaccination against pertussis had 5.6 times higher odds of infection than those who had been immunised according to schedule (Table 3 ).

TABLE 3. Multivariable analysis of pertussis risk factors

\begin{tabular}{|c|c|c|c|c|c|}
\hline \multicolumn{2}{|c|}{ Variable } & $\begin{array}{l}\text { Crude OR } \\
(95 \% \mathrm{CI})\end{array}$ & $\begin{array}{c}\text { Adjusted }{ }^{\mathrm{b}} \mathrm{OR} \\
(95 \% \mathrm{CI})\end{array}$ & $\chi^{2}(\mathrm{df})^{\mathrm{a}}$ & $p$-value \\
\hline \multirow[t]{4}{*}{ Age, months } & $0-1$ & 2.18 & $4.04(0.72,22.64)$ & $2.51(1)^{b}$ & $0.113^{b}$ \\
\hline & 2 & 4.04 & $5.54(1.84,16.71)$ & $9.23(1)^{b}$ & $0.002^{\mathrm{b}}$ \\
\hline & $3-4$ & 0.98 & $1.31(0.42,4.11)$ & $0.21(1)^{\mathrm{b}}$ & $0.646^{\mathrm{b}}$ \\
\hline & $\geq 5$ & 1.00 & 1.00 & & \\
\hline Age-appropriate & Yes & 1.00 & 1.00 & & \\
\hline \multirow[t]{2}{*}{ immunisation } & Unqualified & 2.217 & $0.90(0.23 ; 3.45)$ & $0.03(1)^{\mathrm{b}}$ & $0.873^{b}$ \\
\hline & No & 5.10 & $5.64(1.845,17.245)$ & $9.208(1)^{b}$ & $0.002^{\mathrm{b}}$ \\
\hline
\end{tabular}

${ }^{\mathrm{a}}$ Likelihood ratio test, ${ }^{\mathrm{b}}$ Wald test, $\mathrm{df}$, Degree of freedom 


\section{DISCUSSION}

Our results indicate that young infants are vulnerable to pertussis infection. This finding is consistent with that of other studies (Masseria et al. 2017; Winter et al. 2015). Another study in Malaysia reported similar findings, where the majority of positive PCR results were from children aged $<3$ months (Ting et al. 2013). Due to the immunisation schedule, there is a window of vulnerability for pertussis infection in infants aged $<2$ months. Younger infants are more vulnerable to infection because their immunity has not fully matured. Besides, immunity against infection is not long-lasting, even in people who have previously been infected or immunized, thus rendering young infants more vulnerable (Cherry 2016). If a deduction were to be made based on age group, it would be that the first dose of DTaP does not confer protection against pertussis infection, while the second and third doses do, as shown in the bivariate analysis. Radke et al. (2017) reported a similar finding, where vaccine effectiveness increased with the number of doses received, at least until the primary dose had been completed. However, we observed that although the children might not have received a complete primary dose of DTaP vaccine, receiving vaccination according to their age means that the children would be protected compared to children who have missed their vaccination. This is supported by Glanz et al. (2013), McNamara et al. (2017) and Radke et al. (2017).

The effectiveness of the acellular pertussis vaccine in protecting children according to the number of doses received has been demonstrated (Radke et al. 2017). However, no formal efficacy study has addressed the effect of incomplete primary dose or a single dose (WHO 2017a). The difference recorded in the present study was because $39.7 \%$ of the children had not received their immunization, although one-third of them had attained the appropriate age for vaccination. There might be similar findings in other states in Malaysia, especially those with similar demographic and socioeconomic distribution to Selangor. Through the Malaysia National Health and Morbidity Survey 2016, Lim et al. (2017) noted that the vaccination coverage of DTaP among participants aged 0-59 months was $89.0-89.8 \%$ for the three doses.

In the present study, we found a higher rate of $18.5 \%$ non-vaccinated children among those who qualified for the vaccine. Although the rate appears sufficient for herd immunity level, we should bear in mind that immunity against pertussis is not long-lasting. Hence, this will increase the pool of non-immune people over time. In comparison with regional and global vaccination coverage, which is $85-94 \%$ for DTaP1 and DTaP3 (WHO 2019a, 2019b, 2018c), our findings indicate slightly lower coverage in Malaysia. The MOH has made continual efforts to ensure high vaccine coverage, such as the National
Immunisation Campaign, the provision of immunisation kits to clinics as education material, training healthcare workers as vaccine advocates, forums and seminars with multiagency collaboration, and promotion through social media and mass media (Faridah 2017).

Multiple studies have shown that adult and maternal vaccination of Tdap (Tetanus, diphtheria, acellular pertussis) given during pregnancy is effective for preventing pertussis in new-borns, at least until the child has received their vaccination (Curtis et al. 2017; Forsyth et al. 2015), as breastfeeding does not confer protection against pertussis (Pandolfi et al. 2017). Besides that, a few studies have shown the role of households or mothers as a risk factor for infection (Hughes et al. 2017; Winter \& Harriman 2018). The Advisory Committee on Immunisation Practices (ACIP) recommends a Tdap booster for adults with no previous immunization and a dose of Tdap at 27-36 weeks of gestation during each pregnancy for women regardless of the previous vaccination (Liang et al. 2018). Nevertheless, we found that contact status and relationship were not significant. However, there might be a role for introducing adult or maternal Tdap vaccination to curb pertussis among young infants in Malaysia, as there is evidence of elevated risk of pertussis among younger infants. Tdap vaccination would increase the population's herd immunity and protect younger infants from contracting the infection.

Here, the mean duration of cough among the cases was shorter than the conventional clinical criteria for pertussis, which is 14 days (CDC 2014; WHO 2017b). However, in recent years, international organizations have made an exception for prolonged cough as the clinical criteria, especially among children aged $<1$ year. The Centers for Disease Control and Prevention (CDC) has stated that the presence of apnoea (with or without cyanosis) in infants, paroxysmal cough, inspiratory whoop or post-tussive vomiting with cough of any duration are clinical criteria for pertussis (CDC 2014). A study conducted among infants with critical pertussis in a tertiary healthcare centre in Malaysia noted a mean duration of cough of 1 week (Lin et al. 2016). Meanwhile, a study in North-West Malaysia found that cyanosis was the only symptom associated with pertussis (Salwana et al. 2017), a similar finding to ours. In contrast, a systematic review by Ebell et al. (2017) noted greater susceptibility to whooping cough $(41 \%)$ and post-tussive vomiting (56\%), whilst children were four times more likely than adults to present with whooping cough. However, the overall presentation is the most accurate predictor, rather than individual signs or symptoms (Moore et al. 2017). The authors also noted that vaccinated children tend to lack the typical signs and symptoms of pertussis, explaining the low rate of clinical suspicion among them compared to 
unvaccinated children. A meta-analysis noted that apnoea and cyanosis were both moderately specific and sensitive in infants, while post-tussive vomiting was less helpful as a clinical diagnostic criterion (Moore et al. 2017). Regarding complications, most of the cases developed pneumonia. A study in Peru has reported similar findings (Del ValleMendoza et al. 2018).

\section{LIMITATIONS AND STRENGTHS}

In the present study, the control group comprised those initially suspected as pertussis. Therefore, clinical signs and symptoms were likely to be similar to that in the cases. However, the CDC (2017) has stated there is an increased likelihood of false positive results if an asymptomatic person is tested with PCR, as PCR can detect more cases than culture (Ting et al. 2013). The sensitivity of PCR is $70-99 \%$, with $86-100 \%$ specificity (APHL \& CDC 2010). Several potential confounding factors that may be associated with vaccination status and exposure to pertussis were not included in the study, as the investigation form does not routinely capture such information; examples include coverage of immunity and geography (Curtis et al. 2017; Esposito \& Principi 2016; Levri et al. 2016). However, we were able to match the geographical locations of the cases and controls in the district, which helped to control the factors. Nonetheless, our findings may contribute to explaining the increasing trend of pertussis cases, especially among infants. The study design yielded better strength of association between the risk factors and pertussis infection in the population as compared to a cross-sectional study, and the sampling method ensured that there were representatives for each district in Selangor.

\section{CONCLUSION}

Our study shows that pertussis infection is associated with younger infants, especially those aged $<3$ months, and the role of complying with the vaccination schedule accordingly. Therefore, it is recommended all health facilities ensure that all children are vaccinated according to the national vaccination schedule to ensure that each locality achieves herd immunity. In addition, a strengthened government policy on immunisation schedule, such as compulsory childhood vaccination, should be established.

\section{ACKNOWLEDGEMENTS}

The authors thank the Director General of Health Malaysia and the Dean of the Faculty of Medicine, Universiti Kebangsaan Malaysia, for granting permission to conduct the study. We are also grateful to the DHO staff in Selangor and the Selangor State Health Department for their cooperation during this study. This research received a PPUKM Fundamental Grant from the Universiti Kebangsaan Malaysia Health Centre.

\section{REFERENCES}

Althouse, B.M. \& Scarpino, S.V. 2015. Asymptomatic transmission and the resurgence of Bordetella pertussis. BioMed Central Medicine 13(1): 1-12.

APHL \& CDC. 2010. What's All the Whoop About? It's All About Pertussis Diagnostics. United States: Association of Public Health Laboratories (APHL) \& Centers for Disease Control and Prevention (CDC). Accessed on 6 September 2019.

CDC 2017. Pertussis | Whooping Cough | Use of PCR for Diagnosis | CDC. United States: Centers for Disease Control and Prevention (CDC). Accessed on 8 May 2019.

CDC 2014. Pertussis/Whooping Cough (Bordetella Pertussis) 2014 Case Definition: CSTE Position Statement. United States: Centers for Disease Control and Prevention (CDC). Accessed on 8 May 2019.

Cherry, J.D. 2016. Pertussis in young infants throughout the world. Clinical Infectious Diseases 63(Suppl 4): S119-S122.

Cherry, J.D. 2012. Epidemic pertussis in 2012 - the resurgence of a vaccine-preventable disease. New England Journal of Medicine 367(9): 785-787.

Curtis, C.R., Baughman, A.L., DeBolt, C., Goodykoontz, S., Kenyon, C., Watson, B., Cassiday, P.K., Miller, C., Pawloski, L.C., Tondella, M.L.C. \& Bisgard, K.M. 2017. Risk factors associated with Bordetella pertussis among infants $\leq 4$ months of age in the pre-Tdap era. The Pediatric Infectious Disease Journal 36(8): 726-735.

Deeks, S., De Serres, G., Boulianne, N., Duval, B., Rochette, L., Dery, P. \& Halperin, S. 1999. Failure of physicians to consider the diagnosis of pertussis in children. Clinical Infectious Diseases 28(4): 840-846.

Del Valle-Mendoza, J., Silva-Caso, W., Aguilar-Luis, M.A., Del Valle-Vargas, C., Cieza-Mora, E., Martins-Luna, J., AquinoOrtega, R., Silva-Vásquez, A., Bazán-Mayra, J. \& Weilg, P. 2018. Bordetella pertussis in children hospitalized with a respiratory infection: Clinical characteristics and pathogen detection in household contacts. BioMed Central Research Notes 11(1): 7-12.

DCD 2010. Case Investigation and Outbreak Management for Healthcare Personnel: Pertussis. 1st ed. Malaysia: Ministry of Health Malaysia Disease Control Division (DCD).

Dupont, W.D. \& Plummer, W.D. 1990. Power and sample size calculations: A review and computer program. Controlled Clinical Trials 11(2): 116-128.

Ebell, M.H., Marchello, C. \& Callahan, M. 2017. Clinical diagnosis of Bordetella pertussis infection: A systematic review. Journal of the American Board of Family Medicine: 30(3): 308-319.

Edwards, K.M. 2014. Unraveling the challenges of pertussis. Proceedings of the National Academy of Sciences 111(2): 575-576. 
Esposito, S. \& Principi, N. 2016. Immunization against pertussis in adolescents and adults. Clinical Microbiology and Infection 22: S89-S95.

Faridah, K. 2017. Panel-Roundtable - Country representatives national programs in Asia: Malaysia. Vaccinology 2017- III International Symposium for Asia Pasific Experts.

Forsyth, K., Plotkin, S., Tan, T. \& Von König, C.H.W. 2015. Strategies to decrease pertussis transmission to infants. Pediatrics 135(6): e1475-e1482.

Glanz, J.M., Narwaney, K.J., Newcomer, S.R., Daley, M.F., Hambidge, S.J., Rowhani-Rahbar, A., Lee, G.M., Nelson, J.C., Naleway, A.L., Nordin, J.D. \& Lugg, M.M. 2013. Association between undervaccination with diphtheria, tetanus toxoids, and acellular pertussis (DTaP) vaccine and risk of pertussis infection in children 3 to 36 months of age. JAMA Pediatrics 167(11): 1060-1064.

Hughes, M.M., Englund, J.A., Edwards, K., Yoder, S., Tielsch, J.M., Steinhoff, M., Khatry, S. K., LeClerq, S.C. \& Katz, J. 2017. Pertussis seroepidemiology in women and their infants in Sarlahi district, Nepal. Vaccine 35(48): 6766-6773.

IBM. 2013. IBM SPSS Statistics for Windows, version 22.0. New York: International Business Machines Corporation (IBM).

Koh, M.T., Liu, C.S.S., Chiu, C.H.H., Boonsawat, W., Watanaveeradej, V., Abdullah, N., Zhang, X., Devadiga, R. \& Chen, J. 2016. Under-recognized pertussis in adults from Asian countries: A cross-sectional seroprevalence study in Malaysia, Taiwan and Thailand. Epidemiology and Infection 144(6): 1192-1200

Levri, K.M., Reynolds, L., Liko, J., Dott, M., Robinson, B.F. \& Cieslak, P.R. 2016. Risk factors for pertussis among hispanic infants: Metropolitan Portland, Oregon, 2010-2012. Pediatric Infectious Disease Journal 35(5): 488-493.

Liang, J., Tiwari, T., Moro, P., Messonnier, M., Reingold, A., Sawyer, M. \& Clark, T. 2018. Prevention of pertussis, tetanus, and diphtheria with vaccines in the United States: Recommendations of the advisory committee on immunization practices (ACIP). Morbidity and Mortality Weekly Report: Recommendations and Reports 67(2): 1-44.

Lim, K.K., Chan, Y.Y., Noor Ani, A., Rohani, J., Siti Norfadhilah, Z.A. \& Santhi, M.R. 2017. Complete immunization coverage and its determinants among children in Malaysia: Findings from the national health and morbidity survey (NHMS) 2016. Public Health 153: 52-57.

Lin, C.S., Yiyang, A., Yean, L.E., Shi, K.Y., Chern, C.C. \& Seng, G.C. 2016. A review of critical pertussis in PICU UMMC from 2010-2015. Malaysian Journal of Paediatrics and Child Health 22(101): 2-5.

Masseria, C., Martin, C.K., Krishnarajah, G., Becker, L.K., Buikema, A. \& Tan, T.Q. 2017. Incidence and burden of pertussis among infants less than 1 year of age. Pediatric Infectious Disease Journal 36(3): e54-e61.

McNamara, L.A., Skoff, T., Faulkner, A., Miller, L., Kudish, K., Kenyon, C., Bargsten, M., Zansky, S., Sullivan, A.D., Martin, S. \& Briere, E. 2017. Reduced severity of pertussis in persons with age- appropriate pertussis vaccination-United States, 2010-2012: Milder pertussis in vaccinated people. Clinical Infectious Diseases 65(5): 811-818.
MOH. 2017. Malaysia Health Facts 2017. Malaysia: Health Informatics Centre Planning and Development Division 2016-2017. Ministry of Health Malaysia (MOH). Accessed on 13 May 2019

Moore, A., Ashdown, H.F., Shinkins, B., Roberts, N.W., Grant, C.C., Lasserson, D.S. \& Harnden, A. 2017. Clinical characteristics of pertussis-associated cough in adults and children: A diagnostic systematic review and meta-analysis. Chest 152(2): 353-367.

Pandolfi, E., Gesualdo, F., Carloni, E., Villani, A., Midulla, F., Carsetti, R., Stefanelli, P., Fedele, G. \& Tozzi, A.E. 2017. Does breastfeeding protect young infants from pertussis? Case-control study and immunologic evaluation. Pediatric Infectious Disease Journal 36(3): e48-e53.

Phadke, V.K., Bednarczyk, R.A., Salmon, D.A. \& Omer, S.B. 2016. Association between vaccine refusal and vaccinepreventable diseases in the United States. JAMA 315(11): 1149-1158.

Radke, S., Petousis-Harris, H., Watson, D., Gentles, D. \& Turner, N. 2017. Age-specific effectiveness following each dose of acellular pertussis vaccine among infants and children in New Zealand. Vaccine 35(1): 177-183.

Salwana, K.S., Karniza, K. \& Abdul Nasir, A.M. 2017. Pertussis resurgence in children: A cross-sectional, single centre study in North-West Malaysia. Malaysian Journal of Paediatrics and Child Health Online Early 23(2): 16-23.

Smith, T.C. 2017. Vaccine rejection and hesitancy: A review and call to action. Open Forum Infectious Diseases 4(3): 1-7.

LOM Act 342. 2006. Prevention and Control of Infectious Diseases Act 1988. Malaysia: Laws of Malaysia (LOM).

Ting, T.X., Hashim, R., Ahmad, N. \& Abdullah, K.H. 2013. Detection of Bordetella pertussis from clinical samples by culture and end-point PCR in Malaysian patients. International Journal of Bacteriology 2013: Article ID. 324136.

Tiwari, T., Murphy, T.V. \& Moran, J. 2005. Recommended antimicrobial agents for the treatment and postexposure prophylaxis of pertussis: 2005 CDC Guidelines. Morbidity and Mortality Weekly Report: Recommendations and Reports 54(14): 1-16.

Van Hoek, A.J., Campbell, H., Andrews, N., Vasconcelos, M., Amirthalingam, G. \& Miller, E. 2014. The burden of disease and health care use among pertussis cases in school aged children and adults in England and Wales: A patient survey. PLOS ONE 9(11): 1-14.

Warfel, J.M., Zimmerman, L.I. \& Merkel, T.J. 2016. Comparison of three whole-cell pertussis vaccines in the baboon model of pertussis. Clinical and Vaccine Immunology 23(1): 47-54.

Warfel, J.M., Beren, J. \& Merkel, T.J. 2012. Airborne transmission of Bordetella pertussis. Journal of Infectious Diseases 206(6): 902-906.

Winter, K. \& Harriman, K. 2018. Risk markers for pertussis among infants $<4$ months of age: Understanding the hispanic disparity. Pediatric Infectious Disease Journal 37(2): 126-131.

Winter, K., Zipprich, J., Harriman, K., Murray, E.L., Gornbein, J., Hammer, S.J., Yeganeh, N., Adachi, K. \& Cherry, J.D. 2015. 
Risk factors associated with infant deaths from pertussis: A case-control study. Clinical Infectious Diseases 61(7): 1099-1106.

WHO 2015. Weekly epidemiological record: Position paper on pertussis vaccines. The Weekly Epidemiological Record. Geneva: World Health Organization (WHO) 90(35): 433460.

WHO 2017a. WHO Immunological Basis for Immunization Series Module 4: Pertussis. Geneva: World Health Organization (WHO).

WHO 2017b. Pertussis. WHO-Recommended Standards for Surveillance of Selected Vaccine-Preventable Diseases. Geneva: World Health Organization (WHO).

WHO 2018a. Global and Regional Immunization Profile. Geneva: World Health Organization (WHO).

WHO 2018b. Global and Regional Immunization Profile (Global). Geneva: World Health Organization (WHO).

WHO 2018c. Malaysia: WHO and UNICEF Estimates of Immunization Coverage : 2017 Revision. Geneva: World Health Organization (WHO).

WHO 2019a. Global and Regional Immunization Profile (SouthEast Asia Region). Geneva: World Health Organization WHO.

WHO 2019b. Global and Regional Immunization Profile (Western Pacific Region). Geneva: World Health Organization (WHO).
Yeung, K.H.T., Duclos, P., Nelson, E.A.S. \& Hutubessy, R.C.W. 2017. An update of the global burden of pertussis in children younger than 5 years: A modelling study. The Lancet Infectious Diseases 17(9): 974-980.

Juliana Mansor \& Halim Ismail*

Department of Community Health

Faculty of Medicine

Universiti Kebangsaan Malaysia

56000 Cheras, Kuala Lumpur, Federal Territory

Malaysia

Noriah Ismail

Communicable Disease Control Unit

Selangor State Health Department

40100 Shah Alam, Selangor Darul Ehsan

Malaysia

*Corresponding author; email: halimismail@ppukm.ukm.edu.my

Received: 17 December 2019

Accepted: 24 July 2020 